\title{
Tanning Materials of the British Empire.
}

\section{By Prof. JoHn Read.}

$\mathrm{T}$ HERE is much truth in the old saying that there is nothing like leather; and one rejoices that the tanner continues to thrive in an age which has produced substitutes for so many of the common commodities and witnessed the decline and extinction of so many of the ancient crafts. The exceptional calls which were made upon the leather industry during the War led to an enormous demand for tanning materials, but even under the more settled conditions of the last few years the consumption has shown a steady increase. The total value of such materials used in Great Britain in 1928 was $£ 2,413,000$, of which more than half was imported from foreign countries; this position cannot be considered satisfactory when the supplies available within the British Empire are reviewed.

The examination of tanning materials has taken an important place among the many valuable series of investigations which have been conducted at the Imperial Institute upon natural products from all parts of the Empire. In 1926 an Advisory Committee on Tanning Materials was constituted, and a recent publication ${ }^{1}$ prepared by members of the Institute staff, affords a general account of the chief tanning materials of Empire origin, together with a useful bibliography, and statistics and graphs illustrating consumption and prices in Great Britain. The review includes materials which show promise, in addition to those which have already secured recognition; the classification is under the headings of barks, woods, leaves, fruits, tubers, and miscellaneous materials.

The chief tanning materials grown in Great Britain are oak and larch barks; the combined annual production of about 10,000 tons furnishes, however, only about 7 per cent of the total supply of tannin required for domestic industrial purposes. In spite of its slow rate of penetration into the hide and its high cost, oak-bark tannin is used extensively in producing the best grades of heavy leather. The best English oak bark, grown in Hampshire and Sussex, yields 12-14 per cent of tannin, while good European samples contain 10-13 per cent. Tannin extracts are prepared on the Continent and in North America also from oak wood, which contains 5-13 per cent of tannin; moreover, the cups of the acorns of Quercus AEgilops, with a content of more than 30 per cent, are imported extensively from Asia Minor and Greece under the name of valonia. Within the Empire, oaks occur notably in India, Burma, and New Guinea, but it is in the last-named country only that the possibility of utilising the bark or wood as a source of tannin appears to offer promise.

In 1928 the two main vegetable tanning materials used in Great Britain were quebracho (extract) and myrobalans, and these were followed closely by wattle (bark and extract) and chestnut (extract). A glance at the sources of these four materials reveals several points of much interest. Quebracho

2 “Tanning Materials of the British Empire." Reprinted from the Bulletin of the Imperial Institute. London: Murray, 1929. Price $2 s$. extract is imported exclusively from the Argentine, and the value of this trade has increased from $£ 142,000$ in 1913 to $£ 669,000$ in 1928. There appears to be no fundamental objection to the replacement of much of this material by Empire tannins. Myrobalans, the astringent fruits of various species of Terminalia, are produced extensively in India. The combined value of the fruits and extract used in Great Britain in 1928 was $£ 381,000$, and shipments of almost equal value were made from India to the United States. The pyrogallol tannin of myrobalans has a low rate of penetration and produces a spongy leather; it has consequently been blended with quebracho and other tannins with greater astringency and penetrative power. "Experiments conducted with Empire tanning materials during the War, when there was a shortage of foreign supplies, established the value of the mixed tannage of myrobalans and wattle bark. The astringent, readily penetrating wattle liquors are mellowed by the addition of myrobalans which, through natural fermentation, provide the necessary degree of acidity, and render the leather brighter in colour while diminishing its tendency to become red on exposure to light."

Wattle bark is one of the most abundant and widely used tanning materials of the Empire, and its increasing popularity has led to a careful consideration by the Imperial Institute Advisory Committee of its actual and potential sources of supply. In Australia, the native home of the wattles, there are more than four hundred indigenous species, of which the most important for commercial purposes are Acacia pycnantha (the 'golden wattle' of South Australia) and $A$. mollissima (the ' black wattle', a variety of $A$. decurrens). The best commercial specimens of golden wattle bark ('Adelaide bark') contain about 38 per cent of tannin, but in some instances the air-dried material yields as much as 50 per cent, so that A. pycnantha provides one of the richest known sources of tannin. Black wattle bark sold in the Sydney market gives an average tannin value of about 30 per cent, unless it has been mixed with the inferior bark of the silver wattle (A. dealbata).

At the beginning of the century, Australia enjoyed a thriving export trade in wattle bark, but in 1926-27 the total exports of tan barks (consisting largely of mallet bark from Eucalyptus occidentalis) amounted only to $£ 4010$. Moreover, in the same year the excess of imports over exports of tan

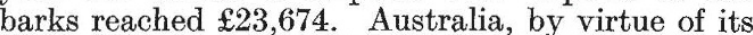
profusion of wattles, Callitris 'pines', eucalypts, and mangroves, possesses unrivalled natural sources of astringents; and yet the paradoxical position has arisen that the Australian leather industry is dependent upon imported tanning materials produced from Australian species of Acacia which have been cultivated in South Africa. The decline in the Australian industry is due to a combination of factors, such as wages, labour supply, depletion of natural forests, and lack of market for the wood. 
Of the total financial return from a wattle plantation in Natal, 56 per cent was derived from the sale of bark, 33 per cent from mine props, and 11 per cent from fuel. Natal, which is now one of the main centres of the wattle bark industry, offers a favourable climate for the cultivation of the black wattle, and at present cheap native labour is available for stripping and handling the bark. "According to the secretary of the Wattle and Timber Growers' Association, the present value of the South African wattle industry may be assessed, at a conservative estimate, at $£ 2,000,000$ a year, of which more than half is money brought into the country by the export of bark and extract." It is therefore not surprising that the Forest Department of the South African Government has organised a comprehensive scheme of sylvicultural research, dealing with growth measurements, standard yields, optimum age, incidence and extent of insect attacks, fertilisers, etc. Encouraging results have also attended the experimental cultiva- tion of A. mollissima and other species in Kenya Colony, Tanganyika, and India.

Chestnut extract is produced mainly from the wood, which when air-dried contains about 8-13 per cent of tannin. The chief producing countries are France, Italy, and the United States, and of the overseas countries of the British Empire only India and Burma offer possibilities for the exploitation of species of chestnut as sources of tannin. Researches carried out at the Forest Research Institute at Dehra Dun have indicated that trees from Burma yield a richer extract than the European trees, but it is doubtful whether the product could be marketed economically under the prevailing conditions.

In these remarks it has been possible to comment only upon a few of the many facts, figures, and investigations finding mention in an unusually interesting publication, which, we are informed, has already been published on the continent in the form of a German translation.

\section{Research in Freshwater Biology and the Functions of a Freshwater Biological Station.}

\section{By Prof. F. E. Fritsch.}

$\mathrm{F}^{2}$ RESHWATERS are put to many different uses. Primarily they are the source of domestic water-supplies, including the huge amount of water required for sanitary purposes. Fresh water is, further, employed in enormous quantities in most, if not all, manufacturing processes. Flowing water is increasingly used as a source of power, while many British waterways serve as a means of communication. An appreciable section of the population, moreover, find relaxation in freshwater fisheries, while many a lake or stream is the centre-point of a beauty spot.

At the same time streams (and sometimes other linds of waters) serve as the natural recipients of sewage, only too often incompletely purified, and of the waste effluentis from a great diversity of chemical works and factories. During the course of the nineteenth century the quick growth of urban populations and the rapid industrial development combined, as a consequence, to bring about a very serious state of pollution in many British rivers, with the result that fish-life was appreciably diminished, and certain kinds, like salmon and trout, disappeared altogether from the more strongly polluted waters. This led to the appointment of a series of Pivers Pollution Commissions, which sat from 1865 onwards, and the reports of which are classical pieces of work which gave to Great Britain a lead of thirty to forty years in water-investigation. Yet, since then, and particularly on the experimental side, we have been far outdistanced by other countries. In the present century, and especially since the War, however, public opinion has again become alive to the evils attendant upon wholesale water-pollution, and various committees have been set up to deal with the matter. Among these, special mention may be made of the Standing Committee on Rivers Pollution appointed by the Ministry of Agriculture and Fisheries in 1921, and the Water Pollution Research Board established in 1927.

The three non-technical reports published by the former Committee (1924-26) contain abundant references both to the lack of scientific knowledge on the organic life of stream and lake and to the need for its acquisition. In the second report (p. 19) it is emphasised as essential that "those responsible for the work of river regeneration should have at their disposal the fullest scientific information bearing on the subject", whilst on p. 24 the same report continues: "At bottom, the problem is doubtless a question of the balance between all the different forms of animal and vegetable life under the particular environmental conditions which prevail ", and (p. 12 of the third report) "it is upon the abundance and well-being of these small organisms that the fish-life ultimately depends".

It is, however, not merely in relation to pollution and fisheries that a complete knowledge of the biology of British freshwaters must be of paramount economic importance. It is no less essential from the point of view of domestic water supplies, while ignorance on this subject is no doubt often the unrecognised cause of difficulties or deficiencies in various manufacturing processes in which water plays a considerable rôle. Moreover, a biological treatment of the effluents may well become a practicable matter in certain cases. Nor can it be doubted that fish-breeding would profit from a more adequate knowledge of aquatic biology.

What, then, is the state of our knowledge as regards the biology of freshwaters in general and of our own in particular? Professional biologists and amateur naturalists have done much to acquaint us with the multifarious aquatic fauna and flora, but there are immense gaps in our knowledge. Collecting has been carried out mostly during the warmer period of the year, and few data are available as regards 